than the figures, not much weight will be placed on the remarkable statements as to the distribution of these forms in the Mexican beds as compared with those in Russia.

This memoir is an important contribution to the Geology of Mexico, and it may be hoped that it is the first of a series which will make known the geological characters of that country in detail.

G. J. H.

\title{
COREESPONDEITCE.
}

\section{REPLY TO PROFESSOR HULL ON THE GLACIAL DEPOSITS OF} ABERDEENSHTRE.

SIR,-Anything Prof. Hull writes is sure of respectful attention in many quarters-not least in that part of the West of Scotland where he laboured during an early stage of his geological career, and where he still has some good friends. From the lettered retreat in which he fitly "crowns a youth of labour with an age of ease," the Professor emerges (in your last Number) to rebuke and exhort a "neo-glacialist" for his errors and "fanciful views" regarding non-submergence and the Glacial period. May the heretic be allowed a few words hy way of reply?

The Glacial deposits of Aberdeenshire consist, it may be repeated, of the following, in ascending, i.e. chronological, order:-

1. Lower Grey Boulder-clay, derived from the rocks of the district.

2. Beds of Gravel and Sand, with water-worn pebbles and fragments of shells.

3. Upper Red Clay, with boulders and a few marine forms.

No. 1 is admitted to be the moraine profonde of an ice-sheet which once extended seaward from the mountainous region on the west. The only questions are regarding 2 and 3 . Under what conditions were they formed? Do they indicate submergence up to, or somewhat beyond, the highest level at which they are found? Or are they also due-under certain changing conditions-to land-ice? The answers to these questions are various :-

Dr. Jamieson says No. 2 does not, but No. 3 does indicate submergence.

The Geological Surveyors say No. 2 does, but No. 3 does not.

Professor Hull says both do.

The only other possible view is also held, viz. that neither indicates submergence.

Now, as Dandie Dinmont used to observe, "that makes an unco difference"; and in such a divided, not to say disorderly, state of opinion on the subject, it seems hardly fair to say, or imply, that anyone trying to throw additional light upon it is animated by an "inpate love of change."

After laying down the grand "rational" rule or principle that "deposits differing in composition and structure from each other should have been formed under different sets of conditions," Prof. Hull goes on to state the "evident succession of conditions" of these three differing superimposed deposits in Aberdeenshire, viz. : 
1. "General land glaciation" (admitted).

2. "Submergence in sea-waters" (?).

3. "Continued submergence" (!).

These are the "different sets of conditions" for the "diversified forms" of deposits 2 and 3 ! Of course, Prof. Hull may explain that other conditions, which may vary, are included under "submergence"; but if so, he must allow glacialists, "neo-" or otberwise, to say the same (with as much, or they may think, more reason) of "glaciation."

We shall look at these other conditions immediately. Meantime it seems almost sufficient to remark that Prof. Hull has first of all to settle matters with Dr. Jamieson. 'That careful observer concluded from his study of the materials of these deposits ( 2 and 3 ) that both had been transported by northward-moving land-ice. Prof. Hull seems to overlook entirely the essential facts which led Dr. Jamieson to this conclusion. These are: first, the presence in both deposits of stones foreign to the district, and not found even in the Grey Till underneath, but, particularly in No. 3, clearly derived from tracts to the south; secondly, striations on rock-surfaces confirming this, showing first a local glaciation from the west, followed by a more general one from the south; and lastly, the fact that the shelly fragments in No. 2 were Iargely of Crag species-pre-Glacial forms-which Dr. Jamieson accounted for by inferring that the northward-moving ice had "scoured out" some area of the Crag along the coast, and conveyed the materials to some extent northward and inland in its progress. All this Prof. Hull overlooks. The result is striking. A deposit containing fragments of Pliocene or pre-Glacial shells and pieces of "yellow limestone and calcareous shale not now found in situ in Aberdeenshire," is supposed to be due simply to an inter-Glacial submergence !-after the country had been swept by a "great ice-sheet," in whose moraine profonde no trace of such rocks or organisms can be found !

Thus it becomes evident that the other conditions which Prof. Hull adds to submergence, even if granted, will not account for the deposits in question. "Sand and gravel brought down by rivers from the adjoining emergent lands" could not contain fragments of rocks not found there either in situ or in fragments, and of which there is no evidence that they have ever been there. Then Prof. Hull supposes that the "continued submergence" was accompanied by "the recurrence of cold conditions"-rather a violent supposition, for the obvious natural tendency of submergence (in this part of the world, at least) would be in the opposite direction, towards milder conditions of climate." But granting the supposition for a moment, it is clear that "glaciers occupying the higher elevations" could not produce a "Red Clay" totally unlike the waste of the rocks of the district (as Dr. Jamieson has pointed out), nor mingle that clay with foreign materials, such as "stones of a volcanic nature unlike the rocks of Aberdeenshire or the North of Scotland,"

1 See this Magazixe for Sept, p. 403. 
but resembling the masses of trap which occur in the Old Red of Forfar and Kincardine.

In short it appears that the facts of the case, with singular perversity, resist all Prof. Hull's endeavours to place them under the "saut water!"

Passing from this, the Professor makes the following remarkable statement: "I would observe that the ice of the North Sea... was only forced over the land while the North Sea was blocked by ice, in which there were neither shells, star-fishes, nor probably seals." Surely Prof. Hull understands that in all such cases the contention is that the ice has transported materials formed in the sea-bed before it was so blocked? If he does not believe in such transport, then he has to settle matters with Sir Arch. Geikie, Dr. James Geikie, Messrs. Peach, Horne, De Rance, Clement Reid, Lamplugh, and many others, before condescending to me! Or are they all "neo-glacialists" together, and alike smitten with "the innate love of change"?

The Professor speaks as one standing on the shore of truth, and looking out over a sea of error, of "the confusion which has arisen among the neo-glacialists regarding the glacial phenomena of the British Isles." It seems very evident that the sect or school of geologists referred to (whoever they may be) did not make the confusion, but only found it.

As Prof. Hull ends by quoting part of a private note from Dr. Joseph Prestwich, I may also close with a sentence from the same high authority-a sentence which may well be taken as a guiding light in all discussions on this subject. In his standard work on "Geology," speaking of those slow movements of the earth's crust, of which the latest evidences are seen in our "Raised Beaches," that distinguished author sums up as follows :"Continuous for long periods in the earlier times, and productive of settlements to be measured, in Cambrian and Silurian times, by thousands of feet, they bave gradually diminished in intensity and power, until, in the later geological times, those great slow continental novements became limited to hundreds, and in more recent times have become reduced to, so to speak. tens of feet, or to a state of comparatively stable equilibrium." - (Vol. ii, p. 525.)

Glasgow, 9 th October.

\section{Dugald Bell.}

Postscript.-I have omitted to notice Prof. Hull's remark on the little sketch map in my paper in the Quarterly Jownal for August. He says-_" On comparing the lines of the ice-movement with the arrows given by Prof. James Geikie in the "Great Ice Age,' they are almost always at right angles : both cannot be correct." This is very astonishing. I wonder what map Prof. Hull has been looking at? Let the reader judge for himself by turning to the map of the "British Isles during the Epoch of Maximum Glaciation" given by Dr. Geikie at p. 69 of the work referred to. There he will see the lines of ice-morement running up along the Aberdeenshire coast, and curving round to N.W. across the Moray Firth, and over the northern part of Caithness, as I have shown them. ${ }^{1}$ Of course it is the recent edition of Dr. Geikie's work that is referred to. Can it be that Prof. Hull

I Anyone wishing confirmation of this may also turn to Croll's map of the Ice-Sheet in North-western Europe, in "Climate and Time," or to Sir A. Geikie's map of the glaciation in his well-known " Scenery and Geology of Scotlaud." 
has been founding his remark on the old map, in the first or second edition of that work, showing only the earlier glaciation on land, and not at all the subsequent ice-movement along the coast? In any case, as Prof. Hull seems to throw doubt on one's accuracy in the matter, it becomes necessary to point out that the mistake is entirely his own, as doubtless he will readily acknowledge.

\section{THE AGE OF THE RHYOLITES OF COUNTY ANTRIM.}

SIR, - The "Proceedings of the Geologists' Association" for August, 1895 (vol. xiv, p. 152), contain a communication made by myself to Mr. R. Lloyd Praeger respecting the probable contemporaneity of the rhyolites of county Antrim and the granite of the Mourne Mountains. This statement was based on notes made by me early in the year, and I had learned, from conversation with Mr. W. W. Watts, that similar views were current among the members of the staff of the Geological Survey of Ireland. Hence the form in which Mr. Praeger utilized the information sent to him.

I wrote, however, in June, before I had received my copy of the Geologioal Magazine for that month, and hence Mr. MeHenry's clear statement of his belief,' though by that time published, was not directly referred to. As soon as I read his paper, I forwarded an account of it, and a withdrawal of any reference to myself, to Mr. Praeger, who revised the amended sentences on his proof's ; but the correction appears to have been overlooked in the press of business connected with a summer excursion of the Association. I make this explanation, since the passage, as published in August, is distinctly unfair to Mr. McHenry's paper, which has thrown such light upon the question.

Grenville A. J. Cole.

Royal College of Science for Ireland, DuBLIN ; Uctober 13th, 1895.

\section{OBITUAEY. \\ ROBERT FITCH, F.S.A., F.G.S. \\ Born Ocrober 21st, $1802 . \quad$ Died April 4th, 1895.}

Geologr, like other branches of Natural History, has owed much of its progress to the zeal of collectors. Of these, one of the most painstaking and successful was the late Robert Fitch, who, in addition to a most valuable collection of antiquities, had gathered together a very fine series of fossils from the Crag and Chalk of Norfolk. He was born at Ipswich, on October 21st, 1802, educated at the Grammar School, and apprenticed to a cbemist and druggist in the town. Pursuing this occupation he settled in Norwich, in 1827, in partnership with Mr. Sheriff Chambers, and continued until he was over 90 years of age to take an active interest in business. From an early date he took great interest in fossils, and his specimens were always at the service of those engaged in palæontological studies.

$\mathrm{He}$ seldom wrote on geological subjects, his chief literary contributions being to the "Transactions of the Norfolk Archæological Society." In 1836, however, he communicated to the Geological Society an account of the discovery of the tooth of a Mastodon in

1 "On the Age of the Trachytic Rocks of Antrim," GEol. MAG. 1895, p. 264. 